\title{
INVESTIGATION OF THE PERCEPTION OF A RADICAL DEGREE OF NOVELTY FROM THE PERSPECTIVE OF PRODUCT USERS
}

\author{
Herrmann, Thorsten; Roth, Daniel; Binz, Hansgeorg \\ University of Stuttgart
}

\begin{abstract}
The dichotomy of radical and incremental innovation has been discussed in numerous literature sources and a great amount of advices on how to handle them in design processes has been provided. Nevertheless, only a minority of literature sources addresses the perception of radicalism from a user's perspective, meaning that there is less research on how users or, in other words, consumers perceive a radical degree of novelty of products. Furthermore, there is little research on how this perception can be measured.

This paper discusses the aforementioned user's perception and proposes a way to derive criteria which users take into account when they decide whether an idea or an innovation is radical or incremental. A concept for an investigative model was developed and applied by using it in the field with 49 test subjects. Consequently, a set of criteria was derived which concretises the decision whether a product was radical or not. The criteria were analyzed statistically and can be used by designers planning to develop a radical innovation in order to check whether the criteria people use to differentiate between radical and incremental products are fulfilled.
\end{abstract}

Keywords: Innovation, Design management, New product development, Radical prodcut idea, Degree of novelty

\section{Contact:}

Herrmann, Thorsten

University of Stuttgart

Institute for Engineering and Industrial Design

Germany

thorsten.herrmann@iktd.uni-stuttgart.de

Cite this article: Herrmann, T., Roth, D., Binz, H. (2019) 'Investigation of the Perception of a Radical Degree of Novelty from the Perspective of Product Users', in Proceedings of the 22nd International Conference on Engineering Design (ICED19), Delft, The Netherlands, 5-8 August 2019. DOI:10.1017/dsi.2019.236 


\section{INTRODUCTION}

For several decades, there has been a scientific discussion of the need for explorative innovations alongside the strengthening of exploitative innovations in order to form ambidexterity within a company's culture, organizational structure and innovation strategy (Duncan, 1976; Koryak et al., 2018). Ambidexterity (Bauer, 2017) is still a much-debated phrase within upper management echelons. In this context, there have been repeated warnings against the disruption described by Christensen et al. (2010). According to these warnings, companies should expand their portfolio management through radical innovations in order to counteract fundamental market changes in their respective technology and innovation fields (Seidenschwarz, 2016). An explorative character is usually attributed to radical innovations, while incremental innovations are more exploitative. Increasingly, radical innovations are thus seen as essential for long-term business success (Bauer, 2017). However, the fact of a radical idea created within an organization becoming an innovation (and by definition, the term innovation should express that it is successful on the market) depends primarily on the consumer and the decision to buy or use a product. The Segway transporter demonstrates that massive product advantages (e.g. flexibility, maneuverability and eco-friendliness) coupled with the fact of being able to travel long distances quickly are not a free pass for success (Tomczak et al., 2016). Therefore, it is important to investigate and to understand the processes of how consumers perceive and evaluate innovations more closely. Within the discussion on ambidexterity, this also involves understanding how a consumer perceives radicalism. While companies primarily innovate from a technological perspective when assessing functional novelty, consumers are particularly concerned with whether and to what extent the innovations offered can be integrated into their everyday lives to give them new experiences and promise concrete benefits (Gourville, 2006).

\section{PROBLEM AND GOAL}

Alongside the entire discussion of ambidexterity, the main aspect of our institute's research is the clear understanding of what makes an innovation or a product idea radical. We will use the term "radical product idea" as a synonym for a radical invention, to be defined as the precursor of a radical innovation (Roberts, 2007). Additionally a radical product idea characterizes an idea for a product with a radical degree of novelty. Our overarching goal is to support designers in the early phases of the design process. Therefore, a method of supporting designers in effectively and efficiently identifying and thus purposefully assessing - radical product ideas must be developed. In doing so, a set of criteria to aid in deciding whether or not an idea is radical is needed in order to support the aforementioned identification step. In an earlier paper, in which we discussed the necessity of identifying radical ideas with a company-based criteria set (Herrmann et al., 2017), we derived four different consideration dimensions. These dimensions consider the perspective from which an idea is to be evaluated as radical. These four consideration dimensions are as follows (Herrmann et al., 2017):

- $\quad$ The market

- The user of the product

- The company's organization/strategy

- The team of designers

So far, only little research into the perception of radicalism by users or customers exists. The detailed goal of this paper is therefore to investigate criteria which users or customers use to perceive radicalism. As some early investigations (e.g. Leifer et al., 2000) have indicated that users apply concrete criteria for the judgement of radicalism (as opposed to an intuitive assessment), the overall research question for this paper is as follows: Which criteria does a product user apply to describe the radicalism of product ideas or innovations? Our goal is to find criteria which users consult when deciding whether or not the degree of novelty of a product is radical and to apply these criteria to product ideas. Other questions that arise from this are whether these criteria can in fact be generalized and whether any differences between users exist in terms of age, gender or expertise in designing, for example. In addition, it must be emphasized that, in this paper, the perception of radicalism should not be linked in detail to a customer's buying decisions and a customer's acceptance. Therefore, to simplify the term, we will only talk about users from this point, whereby "users" can also mean that they are the customer of the producing or selling company and the buyer of the product. Additionally, the paper should support designers who want to design a product with a radical degree of novelty and who want to differ from their competitors while performing significantly better (as opposed to marginally). The result should be that the competitor is unable to catch up so quickly. By deriving criteria which users perceive as radical for products, these 
criteria can be used as a checklist for whether or not their idea or innovation is judged to be radical by a probable user.

\section{METHODOLOGICAL FRAMEWORK OF THE PAPER}

The Design Research Methodology (DRM) according to Blessing and Chakrabarti (2009) constitutes the paper's methodological framework. Within the first step of DRM, the Research Clarification, current understanding and expectations are presented, as are the main research question and requirements (see Section I to III). The second part of DRM, Descriptive Study I, provides a review of the literature on potentially relevant topics and draws overall conclusions. In other words, Descriptive Study I can be characterized as review-based (Blessing and Chakrabarti, 2009). The results of this part are shown in Section 4. In the next section, the focus is on the development of an investigative model due to the fact that Descriptive Study I yielded the result that no such necessary model exists yet and that criteria in the desired form also do not exist. This should be reviewed or verified. As characterized as a Comprehensive Prescriptive Study, this part comprises the task clarification (see Section 4.2), conceptualization, elaboration and the realization and results of a preliminary test in the form of a brief pilot study (see Section 5). The fourth part of DRM, Descriptive Study II, demonstrates the application evaluation for the investigative model. This results in criteria that users consult to describe the radicalism of products from their own perspective. On the basis of these results, overall conclusions are derived and discussed (Section 7). Additionally, further research work will be defined (Section 8).

\section{DESCRIPTIVE STUDY I: LITERATURE REVIEW}

Section 4 is divided into two parts. Section 4.1 presents literature insights into the perception of the radicalism of innovations from a user's perspective. For this purpose, some basics and general definitions are initially introduced in order to foster a broader understanding which will be reinforced in the further course of the paper (see Section 4.1.1). Based on that, results concerning criteria for measuring the user's perception of radicalism are presented (Section 4.1.2). Afterwards, Section 4.2 draws conclusions from literature reviews and clarifies the further tasks to be carried out in the paper.

\subsection{Literature insights}

\subsubsection{Basics and definitions}

In order to clarify the origin of radicalism, the terms in the following section are to be defined. The intensity of an innovation is mostly measured by the degree of novelty. In principle, there are two fundamental approaches for determining the degree of novelty and thus the radical nature of an innovation. The degree of novelty of a product can be judged from the perspective of the manufacturer as well as from that of the user (Halaszovich, 2011).

These two perspectives do not have to influence each other. The degree of novelty can be a continuum between a minimum and a maximum product-variation innovation. These two extremes are termed incremental and radical innovations. On the one hand, incremental innovations are based on an existing product concept and on unchanged links between essential product components. Radical innovations are subject to a greater development risk but offer great market opportunities since fundamental new functions satisfy previously unsatisfied customer demands (Meffert et al., 2015).

\subsubsection{Investigation of criteria for measuring the perception of radicalism by a user}

In order to derive statements and results concerning how users perceive the radicalism of products, different literature databases (Web of Science, ScienceDirect, Google Scholar) were screened for papers and books relating to that topic. As no literature sources provided a concrete investigative model or one dealing with this issue, we broadened the literature research to papers naming criteria which characterize the perception of radicalism by a user. However, the criteria we found are mostly related to criteria which define a high degree of novelty by the user. Excerpts from the sources we found are briefly presented below and transposed to the context of radicalism.

Förster et al. (2010) are the only researchers who specifically present a small list of criteria. They define novelty according to Berlyne (1960) as unexpected, complex, unknown, obscure, uncertain or ambiguous. Basically, novelty is neutral in value and can therefore lead to positive and negative 
reactions. Novelty can be perceived as interesting and normally incites curiosity. It can induce individuals to engage more intensively with a stimulus. On the other hand, something new can be perceived as unsafe, risky (and thus threatening) and can lead to defensive or escape reactions. The assessment of novelty is thus situational and can vary widely. In addition, the perception of novelty is often considered as a highly subjective feeling (Förster et al., 2010).

The user-related assessment of whether a product is novel often depends on the user's knowledge base. If the user respectively the customer perceives that the product is completely unknown to them and the product satisfies completely new needs, the novelty level can be considered very high (Koppelmann, 2001). Studies have shown that the degree of novelty has a significant impact on the perception of an innovation (Meyers-Levy and Tybout, 1989). Products which have a high degree of perceived novelty normally generate attention and interest (Tomczak et al., 2016). Due to a lack of tension and lack of surprise, a feeling of boredom and disinterest arises (Kang et al., 2009). However, with an increasing degree of novelty, consumers feel more and more attracted by knowledge gaps caused by the novelty and respond to this increasingly positively (Meyers-Levy and Tybout, 1989). This is only true for as long as users are able to handle these knowledge gaps and close them. Otherwise, they can react with frustration (Silvia, 2008). Since the goal of the literature research was to investigate criteria for measuring the perception of radicalism, a set of criteria derived from different references is presented in Table 1 in order to complement the insights described above and provide a highly compact form of the results' representation. An earlier paper (Herrmann et al., 2018) by the authors serves as a basis for this criteria set. Within that paper, criteria were derived through systematic research of literature that characterizes radical product ideas in general. The criteria from that paper were complemented by further findings with the focus on the user's perception of radicalism (see Table 1).

Table 1: Criteria for describing users' perception of a radical innovation (literature insights)

\begin{tabular}{|c|c|c|c|}
\hline $\begin{array}{l}\text { CRITERIA users define a radical } \\
\text { product idea with: "Idea is defined } \\
\text { by/based on/delivers/enables..." }\end{array}$ & Reference & $\begin{array}{l}\text { CRITERIA users define a radical } \\
\text { product idea with: "Idea is defined } \\
\text { by/based on/delivers/enables..." }\end{array}$ & Reference \\
\hline $\begin{array}{l}\text { A challenge base for existing technological } \\
\text { order }\end{array}$ & Conti et al., 2014 & Uncertainty & Förster et al., 2010 \\
\hline $\begin{array}{l}\text { A basis for new technologies, future } \\
\text { products, services and/or business } \\
\text { development }\end{array}$ & $\begin{array}{l}\text { Ahuja and Morris Lampert, 2001; Conti et al., } \\
\text { 2014; Dahlin and Behrens, 2005; Datta and } \\
\text { Jessup, 2013; Della Malva et al., 2015; Jung } \\
\text { and Lee, 2016; O'Connor and Rice, 2001 }\end{array}$ & Obscurity & Förster et al., 2010 \\
\hline New fundamental scientific research & Sergeeva and Radosavljevic, 2010 & Ambiguity & Förster et al., 2010 \\
\hline $\begin{array}{l}\text { A high degree of novel technological } \\
\text { content }\end{array}$ & $\begin{array}{l}\text { Conti et al., 2014; Dahlin and Behrens, 2005; } \\
\text { Datta and Jessup, 2013; Della Malva et al., } \\
\text { 2015; Jung and Lee, 2016; Kurkkio et al., } \\
\text { 2011; O'Connor and Rice, 2001; Un, } 2010\end{array}$ & Unfamiliarity & $\begin{array}{l}\text { Förster et al., 2010; Leifer } \\
\text { et al., } 2000\end{array}$ \\
\hline A high degree of new knowledge & Sergeeva and Radosavljevic, 2010; Un, 2010 & Curiosity & Förster et al., 2010 \\
\hline $\begin{array}{l}\text { A recombination of existing knowledge } \\
\text { from several knowledge domains }\end{array}$ & $\begin{array}{l}\text { Della Malva et al., 2015; Schoenmakers and } \\
\text { Duysters, } 2010\end{array}$ & $\begin{array}{l}\text { A previously unrecognized demand } \\
\text { among consumers }\end{array}$ & Förster et al., 2010 \\
\hline Uniqueness & $\begin{array}{l}\text { Ahuja and Morris Lampert, 2001; Dahlin and } \\
\text { Behrens, 2005; Datta and Jessup, } 2013\end{array}$ & Increase in functional reliability & $\begin{array}{l}\text { Förster et al., 2010; } \\
\text { Pleschak and Sabisch, } 1996\end{array}$ \\
\hline Entirely new set of performance features & Leifer et al., 2000 & Risk & Förster et al., 2010 \\
\hline $\begin{array}{l}\text { High improvement in performance: five } \\
\text { times the existing features or greater }\end{array}$ & $\begin{array}{l}\text { Huang et al., 2016; Leifer et al., 2000; } \\
\text { O'Connor and Rice, } 2001\end{array}$ & Satisfying completely new needs & Koppelmann, 2001 \\
\hline Extremely good value & Conti et al., 2014 & Surprise & Kang et al., 2009 \\
\hline Potential reduction of cost & O'Connor and Rice, 2001 & Level of automation & Pleschak and Sabisch, 1996 \\
\hline $\begin{array}{l}\text { A meaningful difference in the lives of } \\
\text { people }\end{array}$ & Harvard Business Review, 2001 & Space requirements & Pleschak and Sabisch, 1996 \\
\hline The obsolescence of existing products & Afuah, 2003 & Variation of control type & Pleschak and Sabisch, 1996 \\
\hline Unexpectedness & Förster et al., 2010 & Mass variation & Pleschak and Sabisch, 1996 \\
\hline Complexity & Förster et al., 2010 & $\begin{array}{l}\text { Product quality/reliability/functional } \\
\text { security }\end{array}$ & Pleschak and Sabisch, 1996 \\
\hline Greater flexibility & Pleschak and Sabisch, 1996 & Integration of functions & Pleschak and Sabisch, 1996 \\
\hline $\begin{array}{l}\text { People's ability to do things they have never } \\
\text { been able to do before }\end{array}$ & Huang et al., 2016 & $\begin{array}{l}\text { Attractiveness (due to lack of } \\
\text { knowledge) }\end{array}$ & $\begin{array}{l}\text { Meyers-Levy and Tybout, } \\
1989\end{array}$ \\
\hline \multirow[t]{2}{*}{ Cost reduction (30 percent or greater) } & Leifer et al., 2000 & Wear behavior & Pleschak and Sabisch, 1996 \\
\hline & & Modularity & Pleschak and Sabisch, 1996 \\
\hline
\end{tabular}

\subsection{Overall conclusions on reviewed literature}

As we learned from the analysis of literature insights, there is no research which investigates the perception of radicalism of products from the perspective of users. We provided a list of criteria which can be used to describe radical products from such a perspective. However, there is neither a fundamental measurement logic to evaluate or rank these criteria, nor to define the degree of radicalism. To contribute to the paper's goal, which is to measure the perception of the radicalism of innovation from the perspective of a product 
user, a model which investigates these criteria must be developed. The greatest challenge is the fact that the investigative model must be able to eliminate subjectivity or create a common set of measures in order to make reliable statements that counteract subjectivity. In other words, the model must be able to eliminate any personal feelings that test subjects might have. However, we assume that the assessment of radicalism is in some way based on people's shared feelings and thus on shared criteria, meaning that a purely subjective assessment can be excluded, as some studies have also shown (see Section 4.1). The criteria to be derived with the investigative model should therefore also be able to be generalized. Additionally, the fact that products with a high degree of perceived novelty generate more attention and interest than products that are very familiar to the user and close to what he or she declares as already known vindicates the need to identify criteria concerning how users perceive the radicalism of products using a measurement model (Meyers-Levy and Tybout, 1989; Tomczak et al., 2016). The degree of novelty has a significant impact on the perception of an innovation (Meyers-Levy and Tybout, 1989). Provided it is feasible to derive criteria describing a user's perception of radicalism, it is possible for all designers to benefit because the attention drawn to their products can likely be increased.

\section{PRESCRIPTIVE STUDY I: INVESTIGATIVE MODEL}

In this section, the investigative model is introduced and explained. Findings on the design of the model itself and results from the preliminary test are presented. The basic idea of the investigative model is to present different examples of radical product ideas (inventions) or radical innovations to different test subjects. The examples are shown on a screen in the form of pictures or short videos. These examples should be analyzed by the respondents during the study. Our goal was to complete the study in less than 45 minutes. After having a preliminary test with several students, six examples proved to be a manageable number with regard to time requirements. Another reason was that the students reported a decline in motivation with an increasing number of examples. Table 2 shows the six examples. In order to present as many different examples as possible, we have selected them according to their degree of awareness. We therefore chose two products which were very new and not yet very common. One of the products was only known from a corporate film and not yet available in the market. Another had just been introduced onto the market by a small start-up. These two examples were shown in short video sequences (approx. 45 seconds) to demonstrate some application scenarios that the test subjects did not yet know about. Four other examples were shown by presenting two pictures at the same time. The first one showed one of the predecessor products of the product in question, while the second showed the innovation which the test subjects were to analyze.

Table 2: Introduction of the six examples used in the study

\begin{tabular}{|c|c|c|}
\hline Example I: Teeth brushing device & Example II: Google Self-driving bike & Example II: Map to navigation system \\
\hline Presenting Method: Video & Presenting Method: Video & Presenting Method: Pair of pictures \\
\hline $\begin{array}{l}\text { Product explanation / functions: } \\
\text { Reservoir with toothpaste, automatically inserted; } \\
\text { cleans teeth within } 3 \text { seconds with the same } \\
\text { quality than before; simultaneous cleaning of all } \\
\text { theft; hands are free during application }\end{array}$ & $\begin{array}{l}\text { Product explanation / functions: } \\
\text { Self-driving bike' } \text {; can be picked up where ever } \\
\text { you are; autonomous driving with or without } \\
\text { driver; you can work (laptop, phone) on your bike } \\
\text { kids can go on the bike without doing anything; } \\
\text { bike will drop while resting (traffic lights etc.) } \\
{ }^{1} \text { No real product (so far). April fool's joke of Google in } 2015 \text {. }\end{array}$ & $\begin{array}{l}\text { Product explanation / functions: } \\
\text { New way to go from A to B; no preparation needed; } \\
\text { scenario should focus on the basic features of an } \\
\text { navigation system }\end{array}$ \\
\hline $\begin{array}{l}\text { Source: } \\
\text { - https://www.trisa.ch/manuelle-zahnbuersten.html } \\
\text { - https://www.trisa.ch/elektrische-zahnbuersten.html } \\
\text { - https://www.indiegogo.com/projects/unico-smartbrush--3/\#/ }\end{array}$ & $\begin{array}{l}\text { Source: } \\
\text { - https://www.umwelt bundesamt.de/themen/verkehr- } \\
\text { laerm/nachhaltige-mobilit aet/radverkehr } \\
\text { - https://www.youtube.com/watch?v=LSZPNwZex9s }\end{array}$ & $\begin{array}{l}\text { Source: } \\
\text { - https://www.welt.de/img/motor/mobile137986536/8311622 167- } \\
\text { ci23x1 1-w780/Autofahrer-vergessene-Handgriffe-8.jpg } \\
\text { - http://www.spiegel.de/auto/aktuell/bild-1 123642-967840.html }\end{array}$ \\
\hline Example IV: Trailer to foldable trailer & Example V: Broom to vacuum cleaner & Example VI: Vacuum cleaner (VC) to robotic VC \\
\hline Presenting Method: Pair of pictures & Presenting Method: Pair of pictures & Presenting Method: Pair of pictures \\
\hline $\begin{array}{l}\text { Product explanation / functions: } \\
\text { Foldable trailer with same sustainable as normal } \\
\text { one; time between unfolded and folded status } \\
\text { approx. one minute; simple pin retentions and } \\
\text { hinges; reduction of length when folded about } 1 / 4\end{array}$ & $\begin{array}{l}\text { Product explanation / functions: } \\
\text { Indoor use of broom } \rightarrow \text { vacuum cleaner (no } \\
\text { special one, just any vacuum cleaner) }\end{array}$ & $\begin{array}{l}\text { Product explanation / functions: } \\
\text { Vacuum cleaner } \rightarrow \text { robotic vacuum cleaner } \\
\text { (Autonomous; with collecting station; self-return } \\
\text { after work) }\end{array}$ \\
\hline $\begin{array}{l}\text { Source: } \\
\text { - https://www.obi.de/aut oanhaenger/stema-anhaenger-basic-sh- } \\
\text { 1300-25-13-1-gebremst/p/2332930 } \\
\text { - https://muschu.com/ }\end{array}$ & \begin{tabular}{|l} 
Source: \\
• https://www.allmystery.de/themen/vo126842 \\
• https://www.dy son.co.uk/cylinders/dyson-ball-multi- \\
floor.html
\end{tabular} & $\begin{array}{l}\text { Source: } \\
\text { - https://www.dyson.co.uk/cylinders/dy son-ball-multi-floor.html } \\
\text { - https://www.kaercher.com/de/nicht-im-aktuellen-sortiment/rc- } \\
\text { 3000-12691010.html }\end{array}$ \\
\hline
\end{tabular}


The purpose of doing so was also to demonstrate the innovation leap by showing the scenario before and after the new product. However, as for the two videos, the test subject was to imagine the innovation leap from the current variation of the product (standard [electric] toothbrush and standard [electric] bike, both of which they may use now). This comparison was also conducted according to the thoughts of Schlaak (1999), who claimed that the assessment of a degree of innovation (radicalism) results from a comparison of an object to be assessed with a suitable object of the status quo used by the appraiser at a certain point during the innovation process.

The whole study starts with a brief introduction and explanation of the terms "radical" and "incremental". The information in Section 4.1.1 is mainly introduced to the test subjects, and some examples are shown (i.e. Volkswagen Golf III to Golf IV for an incremental innovation leap and the leap from the analog technology within cameras to digital cameras as an example of radical innovations). In order to obtain a statement on the perception of radicalism during the study, the test subjects are shown all six examples. After the demonstration, the test subjects are asked whether or not the product shown is radical from their perspective. This decision should be justified and explained briefly. On the basis of this reasoning, the study's moderator includes criteria in each case and queries the test subject on whether these criteria were actually used in the decision.

The next step is to assign a mathematical measurement value to each of the criteria collected which expresses the characteristic of each criterion in relation to the example shown. For this, a scale of 0 100 is provided. The finely graduated scale was chosen to give the respondent a good degree of flexibility in their answers. The procedure can be explained using the following example: The respondent justifies his or her decision that the example shown is radical due to the very high degree of time saving offered by the example. The test subject then assigns a value to the degree of time saving expressed on the scale mentioned, e.g. 85. After this numeric classification has been performed for all criteria mentioned in the example shown, four short questions are asked: Do you know the product shown? Do you own the product shown? Do you like the product shown? Would you purchase the product shown regardless of a possible price? These questions are asked to find out whether there are any connections between the decision concerning whether or not an example is radical and the four aspects asked in the questions mentioned (approval rating for the product, ownership, willingness to purchase or awareness of the example). After this procedure has been completed for all six examples, the respondent is shown a list with all noted criteria (multiple answers were filtered out). Based on the respective criterion, the respondent should now determine the values on a scale of 0-100 from which the criterion appears to be radically pronounced. The answer should not refer to the previously seen examples. This was done to define a threshold value for each criterion. To demonstrate this with an example, the degree of time saving is used again. The test subject should determine a value between 0 and 100, from which level the aspect of time saving of a possible product appears to be radical, e.g. from a value of 65. At the end of the study, participants' age, gender and job title are queried. This is done in order to subsequently form different user groups and investigate whether or not these characteristics have an influence on the decision concerning the radicalism of the examples shown. The results from the preliminary test showed that the investigate model is feasible and the criteria found are similar and comparable. As such, a greater scope of investigation can be applied.

\section{DESCRIPTIVE STUDY II: APPLYING THE INVESTIGATIVE MODEL AND RESULTS}

49 people participated in the study. The average time taken to complete the study was 40 minutes, which perfectly matched the time requirements. As the participants had differing levels of experience with design, we formed three different user groups, which are represented together with additional information (e.g. age range, gender distribution) in Table 3.

Table 3: Distribution of experience level, gender and age of the test subjects

\begin{tabular}{|c|c|c|c|c|c|c|c|c|}
\hline \multirow{2}{*}{$\begin{array}{l}\text { User group } \\
\text { no. }\end{array}$} & \multirow{2}{*}{$\begin{array}{c}\text { Group } \\
\text { description }\end{array}$} & \multirow{2}{*}{$\begin{array}{c}\text { Level of experience in product } \\
\text { design }\end{array}$} & \multirow{2}{*}{$\begin{array}{r}\text { Number of } \\
\text { participants }\end{array}$} & \multirow{2}{*}{$\begin{array}{l}\text { Age } \\
\text { range }\end{array}$} & \multirow{2}{*}{$\frac{\text { Age }}{\emptyset}$} & \multirow{2}{*}{$\begin{array}{l}\text { Standard } \\
\text { deviation }\end{array}$} & \multicolumn{2}{|c|}{$\begin{array}{c}\text { Gender } \\
\text { distribution }\end{array}$} \\
\hline & & & & & & & Female & Male \\
\hline User group 1 & Designers & Experienced in product design & 25 & $25-37$ & 29,68 & \begin{tabular}{|l|}
2,83 \\
\end{tabular} & 4 & 21 \\
\hline User group 2 & Students & Some experience in product design & 12 & $22-29$ & 24,91 & 2,61 & 4 & 8 \\
\hline User group 3 & Non-designers & No experience in product design & 12 & 14-47 & 31,75 & 8,1 & 10 & 2 \\
\hline \multicolumn{3}{|r|}{ All groups } & 49 & 14-47 & 29 & 5,19 & 18 & 31 \\
\hline
\end{tabular}


All entries for criteria or explanations for a criterion that were noted were standardized after the study was carried out, i.e. criteria or notes referring to the same criterion were grouped together in order to identify a single name for the criteria. The criteria always assume a positive change (e.g. reduction of anything [e.g. noise] or increased flexibility, hygiene). From all of the data, we obtained the following results: Firstly, we investigated whether there was a significant difference between user groups in terms of assessing whether or not the six examples were radical. For this purpose, the expected number of yes/no votes from the user groups were compared with the observed numbers that actually occurred and analyzed for all six examples by means of a chi-square test. The same was done for age and gender. For this purpose, the user groups were divided into four age groups ("Generation Z" = younger than $26=9$ test subjects; "Generation Y-young" = older than 25 and younger than $30=17$ test subjects; "Generation Y-old" = older than 29 and younger than $35=17$ test subjects; "Generation X" = older than $34=7$ test subjects). The results in Table 4 allow us to conclude that the characteristics "age" and "experience with product design" did not have any influence on the decision concerning whether or not all examples were radical, since the chi-square test resulted in a typical error value of greater than $\alpha=0.05$ at any time $(0.05$ characterizes the typical probability of error). In other words, the null hypothesis must not be discarded. The null hypothesis of the chi-square test is that there is no difference between observed and expected frequency. We did the same with the outcome of the questions we asked after having shown each example (see Section 5). Again, nearly no influence on the assessment of radicalism was determined (see chi-square in Table 4). In the first example, the aspect of willingness to purchase resulted in a chi-square that was smaller than $\alpha=0.05$. Some tests could not be performed because certain variables of the chisquare tests turned out to be zero as the test subjects unanimously agreed on this aspect anyway (e.g. all owned a vacuum cleaner).

Table 4: Influences on the discussion for a radical degree of novelty of products

\begin{tabular}{|c|c|c|c|c|c|c|c|}
\hline & \multicolumn{7}{|c|}{ Investigation of the influence on the discussion wheter a product is radical or not by ... } \\
\hline & ... age & $\begin{array}{c}\text {... level of } \\
\text { experience within } \\
\text { product design }\end{array}$ & ... gender & ... awarness & ... verdict of fallen & ... ownership & $\begin{array}{l}\text {... willingness } \\
\text { of purchase }\end{array}$ \\
\hline & \multicolumn{7}{|c|}{ Chi-Quadrat according to Pearson / Asymptotic significance (bilateral) } \\
\hline I & 0,617 & 0,329 & 0,098 & 0,166 & 0,140 & \begin{tabular}{|c|}
--- \\
\end{tabular} & 0,021 \\
\hline 11 & 0,308 & 0,538 & 0,753 & 0,117 & 0,325 & --- & 0,788 \\
\hline 111 & 0,521 & 0,595 & 0,9 & --- & --- & --- & --- \\
\hline 坣 IV & 0,781 & 0,181 & 0,961 & 0,265 & 0,248 & --- & 0,555 \\
\hline$\sqrt{\mathrm{V}}$ & 0,209 & 0,207 & 0,185 & --- & --- & --- & --- \\
\hline VI & 0,332 & 0,844 & 0,669 & --- & 0,892 & 0,216 & 0,117 \\
\hline
\end{tabular}

According to Table 4, we can summarize that the age, gender, approval rating, ownership, awareness of the product and in most cases also willingness to purchase the product have no influence on the decision as to whether or not a product or product idea is radical. The most surprising aspect is that there is actually no correlation between the decision and the degree of experience with product design. Indeed, this fact can be underlined by another result. Table 5 shows a ranking of the most frequently mentioned criteria (criteria that are used by at least two thirds of the users) used in the individual user groups to justify whether or not the example shown is radical. The criteria most frequently mentioned in the individual user groups are almost identical across all user groups. Because of this, it can be concluded that the level of experience with regard to product design is irrelevant, even for the criteriabased evaluation or explanation of whether or not a product has been assessed as radical (see Table 5).

Table 5: Most frequently used criteria within the study by user group

\begin{tabular}{|c|c|c|c|c|c|c|c|}
\hline \multicolumn{2}{|l|}{ User group $1(n=25)$} & \multicolumn{2}{|l|}{ User group $2(n=12)$} & \multicolumn{2}{|l|}{ User group $3(n=12)$} & \multicolumn{2}{|l|}{ Total $(n=49)$} \\
\hline Criteria $\quad$ Quantit & Quantity & Criteria $\quad$ Quantit & Quantity & Criteria $\quad$ Quantit & Quantity & Criteria & Quantity \\
\hline Degree of time saving & 25 & Degree of simplification & 12 & Degree of time saving & 12 & Degree of time saving & 48 \\
\hline Degree of simplification & 24 & Degree of functional integration & 11 & Degree of simplification & 11 & Degree of simplification & 47 \\
\hline Degree of benefit of usage & 21 & Degree of time saving & 11 & Degree of space saving & 11 & Degree of benefit of usage & 40 \\
\hline Degree of technological advances & 20 & Degree of technological advances & 10 & Degree of benefit of usage & 10 & Degree of technological advances & 38 \\
\hline Degree of concept modification & 18 & Degree of space saving & 10 & \multirow[t]{3}{*}{ Change in degree of automation } & \multirow[t]{3}{*}{10} & Change in degree of automation & 35 \\
\hline \multirow[t]{2}{*}{ Change in degree of automation } & 17 & Degree of concept modification & 9 & & & Degree of functional integration & 34 \\
\hline & & Degree of benefit of usage & 9 & & & Degree of space saving & 33 \\
\hline $\begin{array}{r}\text { Number of criteria used } \\
\text { within user group in total }\end{array}$ & 40 & $\begin{array}{r}\text { Number of criteria used } \\
\text { within user group in total }\end{array}$ & 36 & $\begin{array}{l}\text { Number of criteria used } \\
\text { within user group in total }\end{array}$ & 34 & $\begin{array}{l}\text { Number of criteria used in total (at } \\
\text { least in one user group) }\end{array}$ & 47 \\
\hline $\begin{array}{r}\text { Number of criteria also to be find in } \\
\text { all other user group }\end{array}$ & 28 & $\begin{array}{r}\text { Number of criteria also to be find in } \\
\text { all other user group }\end{array}$ & 28 & $\begin{array}{r}\text { Number of criteria also to be find in } \\
\text { all other user group }\end{array}$ & 28 & $\begin{array}{l}\text { Number of criteria used at least by } \\
29 \text { users }\end{array}$ & 9 \\
\hline $\begin{array}{r}\text { Number of criteria also to be find in } \\
\text { one other user group }\end{array}$ & 5 & $\begin{array}{r}\text { Number of criteria also to be find in } \\
\text { one other user groups }\end{array}$ & 5 & $\begin{array}{r}\begin{array}{r}\text { Number of criteria also to be find in } \\
\text { one other user group }\end{array}\end{array}$ & 4 & $\begin{array}{l}\text { Number of criteria used at least by } \\
16 \text { users }\end{array}$ & 19 \\
\hline $\begin{array}{r}\text { Number of criteria not to be find in } \\
\text { any other user group }\end{array}$ & 7 & $\begin{array}{r}\text { Number of criteria not to be find in } \\
\text { any other user group }\end{array}$ & 3 & $\begin{array}{r}\text { Number of criteria not to be find in } \\
\text { any other user group }\end{array}$ & 2 & $\begin{array}{l}\text { Number of criteria used by a } \\
\text { maximum of } 5 \text { users }\end{array}$ & 17 \\
\hline
\end{tabular}


This leads us to the conclusion that all of the criteria that were differentiated in the test groups can be combined and that a subdivision into different test groups can be omitted for the further course of investigation; be that according to their level of experience or other aspects (e.g. age, gender or approval rating). In order to answer the main research question concerning which criteria a product user applies to describe the radicalism of product ideas or innovations, we have to conclude that several universal criteria are used to make this judgement. Table 6 shows the entire list of criteria that have been identified during the study. Also listed in Table 6 are the number of mentions, the average threshold value we identified during the study. This average was formed from the individual values of the threshold values of all test subjects. For example, 48 test subjects applied the criterion degree of time saving. From the individual values of the threshold values of all 48 test subjects for the criterion degree of time saving, the average of 63.7 resulted. In addition to that, Table 6 shows the standard deviation of the average thresholds, the standard errors of the average thresholds, and the minimum and maximum values.

Table 6: List of all criteria used by the test subjects

\begin{tabular}{|c|c|c|c|c|c|c|c|c|c|c|c|c|c|c|c|c|c|c|c|c|}
\hline Criteria & 哇 & 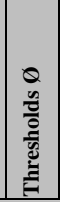 & 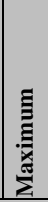 & 吾 & 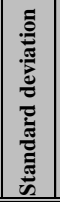 & 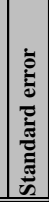 & Criteria & 哭 & 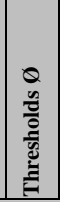 & 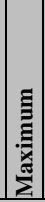 & 要 & 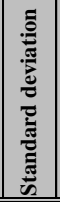 & 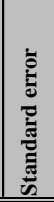 & Criteria & 总 & 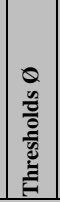 & 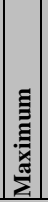 & 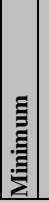 & 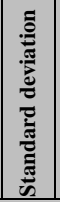 & 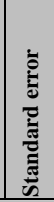 \\
\hline Degree of time saving & 48 & 63,7 & 100 & 30 & 17,5 & 2,5 & \begin{tabular}{|l}
$\begin{array}{l}\text { Degree of } \\
\text { flexibility }\end{array}$ \\
\end{tabular} & 18 & 60,0 & 80 & 30 & 14,2 & 3,3 & $\begin{array}{l}\text { Change in robustness/ } \\
\text { product life time }\end{array}$ & 3 & 56,7 & 80 & 402 & 20,8 & 12,0 \\
\hline Degree of simplification & 47 & 62,4 & 95 & 40 & 14,2 & 2,1 & $\begin{array}{l}\text { Degree of general } \\
\text { novelty }\end{array}$ & 17 & 63,2 & 90 & 35 & $\mid 16,6$ & 4,0 & Degree of reliability & 2 & $|40,0|$ & 60 & 202 & 28,3 & 20,0 \\
\hline Degree of benefit of usage & 40 & 62,5 & 100 & 35 & 16,2 & 2,6 & \begin{tabular}{|l} 
Degree of \\
digitalization
\end{tabular} & 17 & 68,8 & 90 & 40 & $\mid 16,6$ & 4,0 & \begin{tabular}{|l|} 
Degree of \\
serviceability
\end{tabular} & 2 & 76,5 & 75 & $30:$ & 31,8 & 22,5 \\
\hline $\begin{array}{l}\text { Degree of technological } \\
\text { advances }\end{array}$ & 38 & 62,1 & 90 & 10 & 16,3 & 2,6 & $\begin{array}{l}\text { Degree of quality } \\
\text { improvement } \\
\text { within the activity }\end{array}$ & 16 & 55,3 & 80 & 30 & 15,1 & 3,8 & \begin{tabular}{|l}
$\begin{array}{l}\text { Change/introduction } \\
\text { (new) of a business } \\
\text { model }\end{array}$ \\
\end{tabular} & 2 & 52,5 & 83 & 70 & 9,2 & 6,5 \\
\hline $\begin{array}{l}\text { Change in degree of } \\
\text { automation }\end{array}$ & 35 & 59,6 & 90 & 20 & 18,3 & 3,1 & \begin{tabular}{|l} 
Degree of \\
functional change
\end{tabular} & 15 & 53,3 & 80 & 25 & $\mid 18,8$ & 4,8 & $\begin{array}{l}\text { Change of active } \\
\text { principle }\end{array}$ & 2 & 72,5 & 95 & 50 & 31,8 & 22,5 \\
\hline $\begin{array}{l}\text { Degree of functional } \\
\text { integration }\end{array}$ & 34 & 63,1 & 90 & 20 & 15,9 & 2,7 & \begin{tabular}{|l} 
Degree of \\
productivity \\
enhancement
\end{tabular} & 14 & 58,4 & 77 & 40 & 11,3 & 3,0 & \begin{tabular}{|} 
Degree of new \\
combination of known \\
technologies/solutions
\end{tabular} & 2 & 75,0 & 80 & 70 & 7,1 & 5,0 \\
\hline $\begin{array}{l}\text { Degree of space } \\
\text { saving/compactness }\end{array}$ & 33 & 71,1 & 100 & 30 & 19,4 & 3,4 & \begin{tabular}{|l|}
$\begin{array}{l}\text { Expansion of } \\
\text { application }\end{array}$ \\
\end{tabular} & 13 & 62,7 & 80 & 50 & 13,3 & 3,7 & $\begin{array}{l}\text { Degree of confidence } \\
\text { in the product }\end{array}$ & 1 & $|90,0|$ & 90 & 90 & & \\
\hline $\begin{array}{l}\text { Degree of concept } \\
\text { modification }\end{array}$ & 31 & 59,4 & 85 & 30 & 14,5 & 2,6 & $\begin{array}{l}\text { Degree of "wow"/ } \\
\text { surprise effect }\end{array}$ & 12 & 56,9 & 80 & 20 & $\mid 17,9$ & 5,2 & $\begin{array}{l}\text { Degree of increase of } \\
\text { information }\end{array}$ & 1 & $|40,0|$ & 40 & 40 & & \\
\hline Degree of otherness & 29 & 63,0 & 85 & 30 & 14,4 & 2,7 & $\begin{array}{l}\text { Degree of } \\
\text { autonomization }\end{array}$ & 11 & 62,0 & 85 & 48 & 15,0 & 4,5 & $\begin{array}{l}\text { Degree of } \\
\text { miniaturization }\end{array}$ & 1 & 50,0 & 50 & 50 & & \\
\hline $\begin{array}{l}\text { Increase in multitasking } \\
\text { capability }\end{array}$ & 24 & 66,3 & 90 & 40 & 18,5 & 3,8 & $\begin{array}{l}\text { Expansion of the } \\
\text { user group }\end{array}$ & 10 & 63,5 & 85 & 40 & 15,6 & 4,9 & \begin{tabular}{|l}
$\begin{array}{l}\text { Degree of } \\
\text { attractiveness }\end{array}$ \\
\end{tabular} & 1 & 80,0 & 80 & 80 & & \\
\hline Degree of efficiency & 24 & 62,9 & 100 & 40 & 15,2 & 3,1 & $\begin{array}{l}\text { Degree of change } \\
\text { in use }\end{array}$ & 8 & 61,3 & 90 & 35 & 17,5 & 6,2 & Degree of cost saving & 1 & 50,0 & 50 & 50 & & \\
\hline $\begin{array}{l}\text { Degree of safety } \\
\text { enhancement/ } \\
\text { environmental protection }\end{array}$ & 23 & 53,8 & 90 & 30 & 20,1 & 4,2 & $\begin{array}{l}\text { Possibility of } \\
\text { updatability }\end{array}$ & 8 & 66,9 & 90 & 40 & 17,9 & 6,3 & $\begin{array}{l}\text { Degree of noise } \\
\text { reduction }\end{array}$ & 1 & $\mid 95,0$ & 95 & 95 & & \\
\hline Degree of effectiveness & 23 & 67,5 & 100 & 40 & 16,1 & 3,3 & $\begin{array}{l}\text { Performance } \\
\text { enhancement }\end{array}$ & 7 & 71,4 & 95 & 50 & 15,5 & 5,8 & $\begin{array}{l}\text { Degree of hygiene } \\
\text { enhancement }\end{array}$ & 1 & 60,0 & 60 & 60 & & \\
\hline $\begin{array}{l}\text { Degree of functional } \\
\text { enhancement }\end{array}$ & 22 & 63,0 & 80 & 35 & 14,5 & 3,1 & $\begin{array}{l}\text { Degree of } \\
\text { scalability }\end{array}$ & 6 & 50,0 & 95 & 20 & 24,7 & 10,1 & Degree of uniqueness & $\begin{array}{llllll} & 1 & & & & \\
\end{array}$ & $|90,0|$ & 90 & 90 & & \\
\hline $\begin{array}{l}\text { Degree of design (gestalt) } \\
\text { change }\end{array}$ & 21 & 62,6 & 87 & 20 & 19,0 & 4,1 & $\begin{array}{l}\text { Degree of conveni- } \\
\text { ence enhancement }\end{array}$ & 5 & 65,0 & 80 & 50 & 11,2 & 5,0 & Degree of "coolness" & 1 & $\mid \mathbf{5 0 , 0}$ & 50 & 50 & & \\
\hline $\begin{array}{l}\text { Degree of standardization } \\
\text { (quality independent of user) }\end{array}$ & 18 & 58,9 & 90 & 25 & 17,6 & 4,1 & $\begin{array}{l}\text { Degree of environ- } \\
\text { mental friendliness }\end{array}$ & 3 & 40,0 & 50 & 30 & $\mid 10,0$ & 5,8 & & & & & & & \\
\hline
\end{tabular}

It is important to mention that 28 criteria appeared consistently across all three user groups. All criteria were used by at least six test subjects. The 28 commonly used criteria occupied places 1-27 and 30 of the ranking of all criteria used in all three user groups. To add to this, the values to describe the characteristic of the criteria mentioned by the test subjects for the individual examples correlate very well to the initial decision concerning whether or not the examples are radical. This can be seen in Table 7. In the radar charts in Table 7 (only three examples are shown for the sake of ease), the criteria mentioned by at least 10 persons within these examples are shown. 46 of 49 test subjects described the navigation device as radical within the initial question. This good consistency among the test subjects can also be seen on the charts in Table 7. For this example, the average values of the characteristics of the criteria mentioned by the test subjects are above the general average of the respective threshold value of the criteria from Table 6 for almost all criteria (see Table 7, left column). The example of the 
trailer exhibits the exact opposite characteristics: In this case, the given values are below the thresholds, which corresponds with the statement that only 8 of 49 test subjects considered the product to be radical (see Table 7, central column). The test subjects were most uncertain about the robot vacuum cleaner. This was also expressed literally several times during the study. Slightly more than half ( 28 of 49 ) rated the product as radical. This uncertainty is also reflected in the diagram, where it is easy to see that many values are either well above or well below the threshold value (see Table 7, right column). In this example, some criteria are thus expressed as radical and some as incremental, which leads to the uncertainty described by the test subjects. The three examples not shown here also represent a consistent picture of the evaluation of the individual values for the criteria and the general statement concerning the radicalism of the examples.

Table 7: Sample evaluation based on three of the examples shown in the study

\begin{tabular}{|c|c|c|}
\hline Navigation system & Foldable trailer & Robotic vacuum cleaner \\
\hline Criteria consulted in total & Criteria consulted in total & Criteria consulted in total \\
\hline Criteria above average threshold & Criteria above average threshold & Criteria above average threshold \\
\hline Number assessed as radical & Number assessed as radical & Number assessed as radical \\
\hline 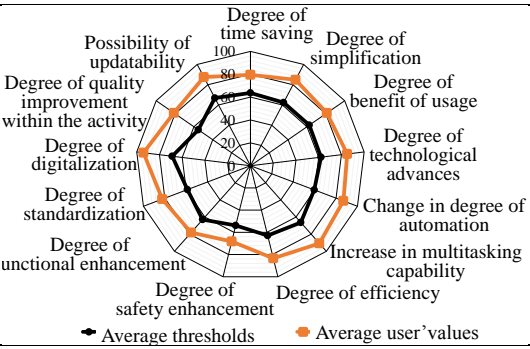 & 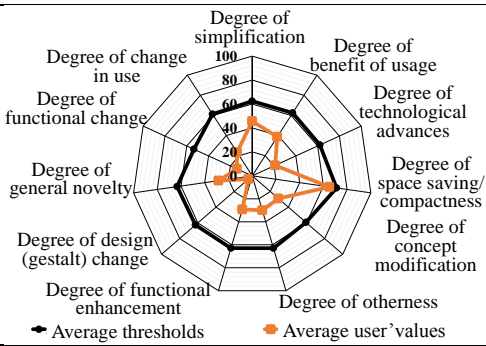 & $\begin{array}{l}\text { Degree of design } \\
\text { (gestalt) change } \\
\text { Degree of } \\
\text { effectiveness }\end{array}$ \\
\hline
\end{tabular}

\section{DISCUSSION AND CONCLUSION}

In order to discuss the paper's results, evidence of whether or not the research question was answered should be provided. The goal was to present a set of criteria which users take into account while describing the radicalism of innovations or ideas. Table 6 presents a list of criteria derived along with the investigative model presented. The research question was thus able to be answered. Furthermore, one additional question concerned whether or not these criteria can actually be generalized. It has been shown that numerous criteria were used by a significant number of test subjects (Table 6). Of all 47 criteria, 9 were used by at least half of the test subjects. Additionally, we showed that any differences between users in terms of age, expertise in design, gender, awareness, approval rating for products, ownership or willingness to purchase are characteristics which are independent of the judgement of a radical degree of novelty of products. If the general criteria derived from the literature (Table 1) are compared to the criteria derived from the test subjects within the study, we can determine that 11 of the study's 49 criteria can be found in the criteria set from the relevant literature. Therefore, the study has provided different criteria with which users can assess the radicalism of products. The study thus extends the set of criteria derived from literature. Nevertheless, the criteria must be verified through a further extended study and applied to a broader product spectrum. What the study also showed is that - in the rarest cases - the radicalism of a product is not determined by a single criterion, rather by multiple criteria. Various aspects have to be satisfied in order to define a product as radical. The threshold values are close to a value of 63 and represent just under two thirds of the scale. This value stabilizes as the number of mentions for a criterion increases (Table 6).

\section{OUTLOOK}

As the study was an initial investigation to show that the perception of radicalness of an innovation from a user's perspective is actually measurable, further and deeper investigation should follow. Firstly, the product spectrum within the investigative model should be broadened to verify whether criteria can be added or whether these are based on a specific product's characteristics. Secondly, the investigative model can be adapted. As an initial proposal, a joint analysis can be used in which different product variants are presented. This would involve the product variants being changed during the analysis according to the criteria found in this paper. By doing so, the detected criteria and also the thresholds can be verified. As proposed at the end of Section 2, the supporting effect for designers must be proven. In other words, if designers use the criteria identified in this paper as a checklist in order to prove whether 
or not products to be designed are radical from a user's perspective, evidence should be provided in the form of concrete product examples as to whether or not the products turn out to be radical when launched onto the market. The supporting effect for the designer thus needs to be evaluated.

\section{REFERENCES}

Bauer, W. (2017), Innovation Management 2025, Open Innovation Kongress, Stuttgart, Germany.

Berlyne, D.E. (1960), Conflict, arousal, and curiosity, McGraw-Hill Book Company, New York.

Blessing, L.T.M. and Chakrabarti, A. (2009), DRM, a Design Research Methodology, Springer, London.

Christensen, C.M., von der Eichen, S.F. and Matzler, K. (2010), Innovators Dilemma, Vahlen, München.

Duncan, R.B. (1976), "The ambidextrous organization: designing dual structures for innovation", Management Organisation, Vol. 1, pp. 167-188.

Förster, J., Marguc, J. and Gillebaart, M. (2010), "Novelty Categorization Theory”, Social and Personality Psychology Compass, Vol. 4 No. 9, pp. 736-755.

Gourville, J.T. (2006), "Eager sellers and stony buyers: understanding the psychology of new-product adoption", Harvard Business Review, Vol. 84 No. 6, pp. 98-106, 145.

Halaszovich, T.F. (2011), Neuprodukteinführungsstrategien schnelldrehender Konsumgüter, Gabler Verlag / Springer Fachmedien Wiesbaden GmbH Wiesbaden, Wiesbaden.

Herrmann, T., Binz, H. and Roth, D. (2017), "Necessary extension of conventional idea processes by means of a method for the identification of radical product ideas", In: Maier, A., Škec, S., Kim, H., Kokkolaras, M., Oehmen, J., Fadel, G., Salustri, F. and van der Loos, M. (Ed.), DS 87-8 Proceedings of the 21st International Conference on Engineering Design (ICED 17), Vancouver, Canada, pp. 79-88.

Herrmann, T., Roth, D. and Binz, H., (2018), "Derivation of criteria for radical product ideas", In: Marjanović, D., Štorga, M., Škec, S. Bojčetić, N. and Pavković, N. (Ed.), DS92: Proceedings of the DESIGN 2018: 15th International Design Conference, Faculty of Mechanical Engineering and Naval Architecture, University of Zagreb, Croatia; The Design Society, Glasgow, UK, pp. 1867-1878.

Kang, M.J., Hsu, M., Krajbich, I.M., Loewenstein, G., McClure, S.M., Wang, J.T.-y. and Camerer, C.F. (2009), "The wick in the candle of learning: epistemic curiosity activates reward circuitry and enhances memory", Psychological science, Vol. 20 No. 8, pp. 963-973.

Koppelmann, U. (2001), Produktmarketing, Springer, Berlin [u.a.].

Koryak, O., Lockett, A., Hayton, J., Nicolaou, N. and Mole, K. (2018), "Disentangling the antecedents of ambidexterity: Exploration and exploitation", Research Policy, Vol. 47 No. 2, pp. 413-427.

Leifer, R., McDermott, C.M., Peters, L.S., Rice, M.P. and Veryzer, R.W. (2000), Radical innovation, Harvard Business School Press, Boston.

Meffert, H., Burmann, C. and Kirchgeorg, M. (2015), Marketing, Springer Gabler, Wiesbaden.

Meyers-Levy, J. and Tybout, A.M. (1989), "Schema Congruity as a Basis for Product Evaluation", Journal of Consumer Research, Vol. 16 No. 1, pp. 39-54. URL http://www.jstor.org/stable/2489300,

Schlaak, T.M. (1999), Der Innovationsgrad als Schlüsselvariable, Deutscher Universitäts-Verlag, Wiesbaden.

Seidenschwarz, W. (2016), "Portfoliomanagement, Band I", In: Lindemann, U. (Ed.), Handbuch Produktentwicklung, Carl Hanser Verlag, München, pp. 37-58.

Silvia, P.J. (2008), "Interest-The Curious Emotion", Current Directions in Psychological Science, Vol. 17 No. 1 , pp. 57-60.

Tomczak, T., Vogt, D. and Frischeisen, J. (2016), "Wie Konsumenten Innovationen wahrnehmen Neuartigkeit und Sinnhaftigkeit als zentrale Determinanten”, In: Hoffmann, C.P., Lennerts, S., Schmitz, C., Stölzle, W. and Uebernickel, F. (Ed.), Business Innovation: Das St. Galler Modell, Springer Gabler, Wiesbaden, pp. 187-209. 